\title{
High effective silica fume alkali activator
}

\author{
VLADIMÍR ŽIVICA \\ Institute of Construction and Architecture of the Slovak Academy of Sciences, Dúbravská cesta 9, 84503 \\ Bratislava 45, Slovak Republic
}

MS received 11 November 2003

\begin{abstract}
Growing demands on the engineering properties of cement based materials and the urgency to decrease unsuitable ecologic impact of Portland cement manufacturing represent significant motivation for the development of new cement corresponding to these aspects. One category represents prospective alkali activated cements. A significant factor influencing their properties is alkali activator used. In this paper we present a new high effective alkali activator prepared from silica fume and its effectiveness. According to the results obtained this activator seems to be more effective than currently used activators like natrium hydroxide, natrium carbonate, and water glass.
\end{abstract}

Keywords. Alkali activation; slag; Portland cement; slag blends; silica fume; alumino-silicates.

\section{Introduction}

Growing demands on the engineering properties of cement based materials and ecological aspects in the manufacture of Portland cement are some of the motivation factors for the development and use in building practice of the cements corresponding to these aspects (Davidovits 1993). The binding systems based on the alkali activation represent a group of cements of this category (Davidovits 1994).

Alkali activated cements (AAC) are the type of the binders synthesized from natural alumino-silicate materials and alumino silicate waste products such as flyash, rice husk ash, slag, etc which are rich in silicium and aluminium (Herr 2002). Therefore, the use of alkali activation technology enables the possibility of substantial utilization of waste materials. Moreover, it seems that AAS are able to enable in some respects some better engineering properties opposite to those of Portland cements (Anderson et al 1988; Gjǿrv 1989).

Alkali activation is a process based on the action of solutions of alkali compounds like natrium or kalium hydroxide, natrium carbonate and silicate on the aluminosilicate constituent of the binder. The result is the destruction of the chemical bonds of the type $\mathrm{Si}-\mathrm{O}-\mathrm{Si}$ in the aluminosilicate.

Various hydration products are the result of alkali activation like calcium silicate hydrates, alkali calcium aluminosilicate hydrates, gehlenit and hydrogarnet hydrates. It is known that the efficiency of an alkali activator is very strongly dependent on the physicochemical nature of the material to be activated. The presence of amorphous phases, in particular from the system, $\mathrm{CaO}-\mathrm{Al}_{2} \mathrm{O}_{3}-\mathrm{SiO}_{2}$, plays a significant role due to its considerable reactivity towards alkalies. Then, naturally towards the process of alkali activation.
Naturally the effectiveness of the alkali activator is a very significant factor influencing the intensity and rate of process of alkali activation (Wang et al 1994; Ski and Day 1996). It is reported that the best activator is water glass (Slota 1987). Its best dosage is within the range of $3 \cdot 0-5 \cdot 5 \% \mathrm{Na}_{2} \mathrm{O}$ by weight of slag. The optimum dosage ranges of water glass solution are $0.75-1.25 \%$ for acid slag, $0.90-1.30 \%$ for neutral slag, and $1.0-1.5 \%$ for basic slag. The optimum range of fineness is $4000-5500 \mathrm{~cm}^{2} / \mathrm{g}$.

It is evident that the effectiveness of activator is a very significant factor which determines the engineering properties of the material. Therefore, the effectiveness of alkali activator represents the aim worthy of attention for further research. The subject of the paper is a new type of alkali activator prepared from silica fume (SFA) developed in the author's laboratory. Here the effectiveness of SFA as the activator of slag binder systems is shown.

\section{Experimental}

For the study of the effectiveness of SFA, mortar $(20 \mathrm{~mm})$ edge cubes from Portland cement (CEM I 42.5 according to STN PEN V 197-1), their slag blends, and slag, were prepared. Cement : sand ratio was $1: 3$ (STN 71 1208). The fresh mortar mixtures were prepared adding SFA, natrium hydroxide and water glass. For comparison the mortar mixtures with water addition were prepared. The criterion of the dosage was the equivalent workability based on the test according to the standard STN 722441.

SFA used represents a solution-a product gained from defined suspension of silica fume and water solution of alkali compound. The suspension was cured under the defined ambient temperature and time of action of alkali solution on silica fume. 
Table 1. Chemical composition and properties of the materials used.

\begin{tabular}{|c|c|c|c|}
\hline Composition (\%) & $\begin{array}{l}\text { Portland cement } \\
\text { CEM I } 42 \cdot 5 \\
\text { Mokrá }\end{array}$ & $\begin{array}{l}\text { Silica fume } \\
\text { Široká }\end{array}$ & $\begin{array}{l}\text { Blast furnace } \\
\text { slag Trinec }\end{array}$ \\
\hline Loss on ignition & $1 \cdot 38$ & $2 \cdot 35$ & $2 \cdot 25$ \\
\hline Insoluble residue & $1 \cdot 18$ & $2 \cdot 34$ & - \\
\hline $\mathrm{SiO}_{2}$ & $20 \cdot 91$ & $94 \cdot 14$ & $37 \cdot 14$ \\
\hline $\mathrm{CaO}$ & $62 \cdot 18$ & $0 \cdot 13$ & $37 \cdot 40$ \\
\hline $\mathrm{Al}_{2} \mathrm{O}_{3}$ & $5 \cdot 82$ & $0 \cdot 13$ & $9 \cdot 15$ \\
\hline $\mathrm{Fe}_{2} \mathrm{O}_{3}$ & $3 \cdot 40$ & $0 \cdot 18$ & 1.05 \\
\hline $\mathrm{MgO}$ & $2 \cdot 36$ & $0 \cdot 18$ & 11.70 \\
\hline $\mathrm{SO}_{3}$ & $2 \cdot 78$ & $0 \cdot 28$ & $0 \cdot 37$ \\
\hline Spec. weight $\left(\mathrm{g} \cdot \mathrm{cm}^{-3}\right)$ & $3 \cdot 116$ & $2 \cdot 269$ & $2 \cdot 842$ \\
\hline Spec. surface $\left(\mathrm{m}^{2} \cdot \mathrm{kg}^{-1}\right)$ & $334 \cdot 3$ & 15898 & $231 \cdot 5$ \\
\hline $\begin{array}{l}\text { Normal consistency } \\
\text { Setting. }\end{array}$ & \multicolumn{2}{|l|}{29} & $\begin{array}{c}\text { Maximal size } \\
\text { of grain, } 90 \mu \mathrm{m}\end{array}$ \\
\hline $\begin{array}{l}\text { Setting: } \\
\text { beginning } \\
\text { end }\end{array}$ & \multicolumn{2}{|l|}{$\begin{array}{l}2 \mathrm{~h} 45 \min \\
\quad 4 \mathrm{~h}\end{array}$} & \\
\hline \multicolumn{4}{|c|}{$\begin{array}{l}\text { Mineralogical composition (Bogue) }-\% \\
\mathrm{C}_{3} \mathrm{~S}-42 \cdot 46 ; \mathrm{C}_{3} \mathrm{~A}-9 \cdot 73 ; \mathrm{CaSO}_{4}-6 \cdot 03 ; \mathrm{C}_{2} \mathrm{~S}-27 \cdot 90 ; \mathrm{C}_{4} \mathrm{AF}-10 \cdot 21\end{array}$} \\
\hline
\end{tabular}

The moulds with fresh mortar test specimens were cured for $24 \mathrm{~h}$ at relative humidity of ca $95 \%$, and after demoulding in water at ambient temperature of $20^{\circ} \mathrm{C}$.

The properties of the test specimens studied were compressive strength, chemically bound water, and hydration products produced using SDT 2960 device and standard thermal analysis programme T.A., pore structure (total porosity of portion macro pore with radius over $7500 \mathrm{~nm}$, pore median, surface area), using CARLO ERBA mercury intrusion porosimeter mod 2000.

Information on the properties of the material used is given in table 1 .

\section{Results and discussion}

\subsection{Compressive strength}

The development of compressive strength of the test specimens is shown in figure 1. It is evident that the mortars prepared by the application of SFA show higher values of compressive strength mainly after 28 days of hardening opposite to those prepared with $\mathrm{NaOH}$, water glass, and water. This comparison documents the higher effectivity of SFA opposite to the effect of two mentioned activators, and water.

A comparison of the effectiveness of SFA and some currently used activators is shown in figure 2 . The high effectiveness of SFA further confirms the comparison of the compressive strength values of the mortar mixtures No. 6 and No. 8 with SFA prepared from blends containing 30 and $10 \%$ of Portland cement opposite to the mortar No. 2 prepared from Portland cement and water. Significantly higher values of compressive strength reached

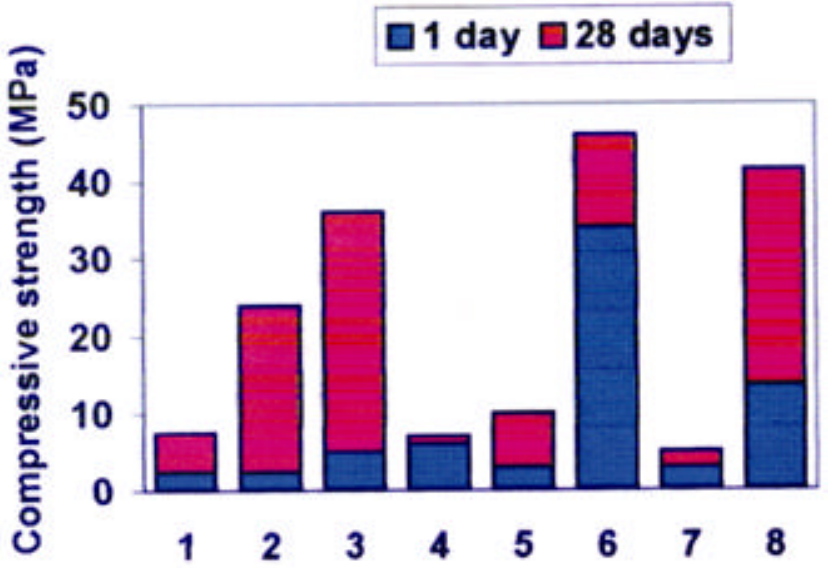

Figure 1. Development of compressive strength of mortars depending on the alkali activator used and the composition of the binder and the time of hardening. 1. Slag $+\mathrm{NaOH} ; 2$. Silica fume activator + slag; 3 . Portland cement + water; 4 . $70 \%$ Portland cement $+30 \%$ slag + water glass; $5.30 \%$ Portland cement $+70 \%$ slag + water; $6.30 \%$ Portland cement $+70 \%$ slag + silica fume activator; 7. $10 \%$ Portland cement $+90 \%$ slag + water; 8. $10 \%$ Portland cement $+90 \%$ slag + silica fume activator.

after 28 days of hardening with application of SFA are clearly evident.

\subsection{Chemically bound water and pore structure}

The results of estimation of the chemically bound water are given in table 2. For the content in chemically bound water the values of loss on ignition estimated by GTA in the interval $100-500^{\circ} \mathrm{C}$ were considered. 


\section{$\square 1$ day $\square 28$ days}

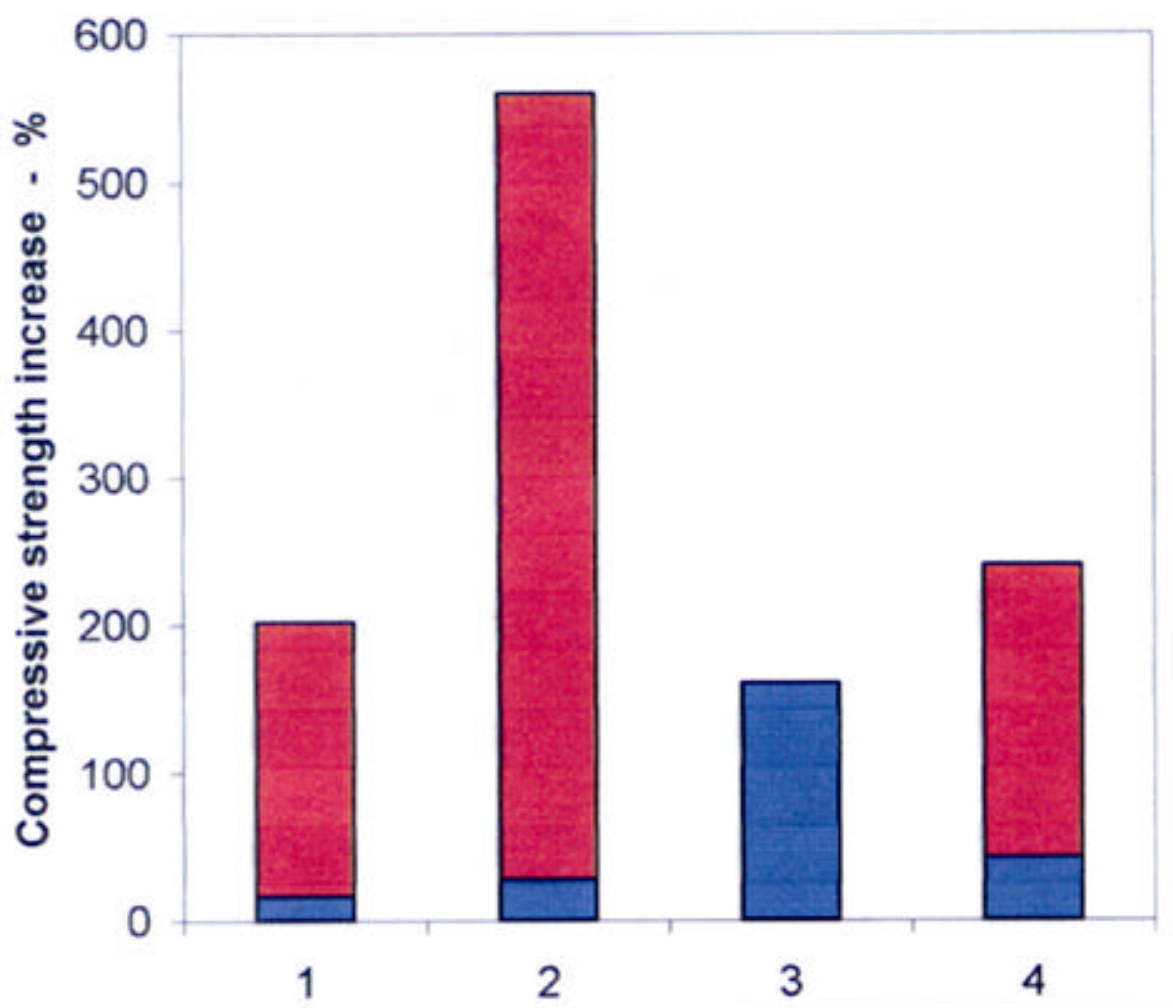

Figure 2. Comparison of the effectiveness of the alkali activator used. 1. Slag, silica fume activator opposite to natrium hydroxide; 2 . $30 \%$ Portland cement $-70 \%$ slag, silica fume activator opposite to water; 3. $10 \%$ Portland cement $-90 \%$ slag, silica fume activator opposite to water, 1 and 28 days values are equal; 4. Slag, silica fume activator opposite to water glass.

Table 2. Composition of mortar mixtures, content in water bound and pore structure parameters after 28 days of hardening.

\begin{tabular}{|c|c|c|c|c|c|c|c|}
\hline \multicolumn{3}{|c|}{ Composition of the mixture } & \multirow{2}{*}{$\begin{array}{c}\text { Content } \\
\text { chemically } \\
\text { bound water }(\%)\end{array}$} & \multirow[b]{2}{*}{$\begin{array}{c}\text { Total } \\
\text { porosity }(\%)\end{array}$} & \multirow{2}{*}{$\begin{array}{c}\text { Portion of } \\
\text { macropores } \\
r>7500 \mathrm{~nm}(\%)\end{array}$} & \multirow{2}{*}{$\begin{array}{l}\text { Specific } \\
\text { surface area } \\
\left(\mathrm{m}^{2} / \mathrm{g}\right)\end{array}$} & \multirow{2}{*}{$\begin{array}{l}\text { Pore } \\
\text { median } \\
(\mathrm{nm})\end{array}$} \\
\hline $\begin{array}{l}\text { Portland } \\
\text { cement }\end{array}$ & Slag & $\frac{L}{B}$ & & & & & \\
\hline 30 & 70 & $\begin{array}{c}0.52 \\
\text { water }\end{array}$ & $1 \cdot 37$ & $18 \cdot 9$ & $21 \cdot 06$ & $5 \cdot 0$ & 19 \\
\hline 30 & 70 & $\begin{array}{l}0 \cdot 74 \\
\text { SFA }\end{array}$ & $1 \cdot 01$ & $10 \cdot 9$ & $24 \cdot 00$ & $4 \cdot 2$ & 11 \\
\hline 10 & 90 & $\begin{array}{c}0.52 \\
\text { water }\end{array}$ & $3 \cdot 30$ & $20 \cdot 1$ & $17 \cdot 08$ & $3 \cdot 3$ & 20 \\
\hline 10 & 90 & $\begin{array}{l}0 \cdot 74 \\
\text { SFA }\end{array}$ & $3 \cdot 30$ & $12 \cdot 5$ & $27 \cdot 55$ & $3 \cdot 3$ & 13 \\
\hline- & 100 & $\begin{array}{c}0 \cdot 42 \\
\text { water } \\
7 \% \mathrm{Na}_{2} \mathrm{O}\end{array}$ & $2 \cdot 69$ & $23 \cdot 8$ & $38 \cdot 34$ & $2 \cdot 7$ & 24 \\
\hline- & 100 & $\begin{array}{l}0 \cdot 80 \\
\text { SFA }\end{array}$ & 1.43 & $16 \cdot 8$ & $33 \cdot 70$ & $1 \cdot 4$ & 17 \\
\hline
\end{tabular}

$\frac{L}{B}$, ratio of dosage of water or SFA and binder. 
According to the results obtained, it may be seen that the content in chemically bound water or the hydration products, respectively was in the mortars with application of SFA lower or equal to this estimated in the mortars prepared with water.

The values of pore structure parameter also given in table 2 show the lower values of total porosity and pore median at the SFA mortars opposite to those prepared with water. Opposite relationship in the values of macropore portion and surface area may be observed. The decreased total porosity indicated an increased content of hydration products in the SFA mortars. The decreased content of chemically bound water found indicates that the hydration products produced under the application of SFA were the compounds with decreased content in chemically bound water. Therefore, even the content in chemically bound water should be higher. But it was found that this was lower. Therefore, it may be assumed that the hydration products produced under the application of SFA are compounds having lower content in the chemically bound water as those produced under the use of water.

The decreased pore median values found indicate that the hydration produced under the application of SFA may formate finer pore structure than those produced at the use of water. Both the effects-porosity and pore median decrease-are known as factors contributing to the positive development and strength increase of cement based materials. It was evident from SFA application.

The results of both positive pore structure effects of SFA application may be, however, limited in some extent by the adverse effects contributing to the decrease of compressive strength. These represent increased values of macropore portion, and decreased values of specific surface area of SFA mortars opposite to those at the use of water (table 2). Both considered effects are known as factors influencing slowing down of strength development and their decrease.

\section{Conclusions}

The results obtained show high alkali activation effectiveness of new silica fume activator. As it has been shown it significantly overcomes the current alkali activators like natrium hydroxide and water glass. Therefore, silica fume activator seems to be worthy of further attention in the interest of further increase of its effectiveness. The following topics of research seem to be interesting and useful:

- the dependence of effectiveness of activator on the chemical and mineralogical composition of the material to be activated,

- the possibility of elimination of the found negative effect of the silica fume activator application on the development of pore structure of the activated material occurring as an increase of the content in macropores.

\section{Acknowledgement}

The author would like to thank the Slovak Grant Agency, VEGA, for its support of this work (grant 2/3039/23).

\section{References}

Anderson A, Gram H E, Malolepszy J and Dejy J 1988 Alkali activated slag (Stockholm: Swedish Cement and Concrete Research Institute) p. 104

Davidovits J 1993 Ceram. Trans. 37165

Davidovits J 1994 High alkali cements for 21st century concretes, Concrete technology past, present and future, V. Mohan Malhotra Symposium (ed.) P Kumar Mehta (Detroit: American Concrete Institute) pp 383-397

Gjǿrv O E 1989 Alkali activation of Norwegian granulated blast furnace slag, 3rd int. conf. on flyash, silica fume, slag and natural pozzolan in concrete (ed.) V M Malhotra (Detroit: American Concrete Institute), Vol. 2, pp 15011517

Herr R 2002 Die Entwicklung von Baustoffen nach dem Prinzip der Geopolymerization, IEMB, Neue Ergebnise 2002, 6 ps What is geopolymer? www.geopolymer.org/about $3 . \mathrm{html}$

Ski Caijun and Day R L 1996 Cem. \& Concr. Res. 26439

Slota R J 1987 Cem. \& Concr. Res. 17703

Wang Shao-Dong, Scrivener K L and Pratt P L 1994 Cem. \& Concr. Res. 241033 